This is a non-peer-reviewed manuscript submitted to EarthArxiv. The manuscript was submitted for review to Geophysical Research letters.

\title{
Using thermal springs to quantify deep groundwater flow and its thermal footprint in the Alps and North American orogens
}

\section{Elco Luijendijk ${ }^{1,2}$, Theis Winter ${ }^{1,3}$, Saskia Köhler ${ }^{1,4}$, Grant Ferguson ${ }^{5}$, Christoph von} Hagke $^{2,6}$, Jacek Scibek ${ }^{7}$

${ }^{1}$ Department of structural geology \& geodynamics, University of Göttingen, Goldschmidtstrasse 3, 37077, Göttingen, Germany

${ }^{2}$ Geological Institute, RWTH Aachen University, Wüllnerstr. 2, 52056 Aachen, Germany.

${ }^{3}$ Faculty of Civil, Geo and Environmental Engineering, Technical University of Munich, Arcisstr. 21, 80333 Munich, Germany

${ }^{4}$ GeoZentrum Nordbayern, Universität Erlangen-Nürnberg, Schlossgarten 5, 91054 Erlangen, Germany

${ }^{5}$ Department of Civil, Geological and Environmental Engineering, University of Saskatchewan, 57 Campus Drive, Saskatoon, Canada

${ }^{6}$ Department of Geography and Geology, University of Salzburg, Hellbrunnerstrasse 34 A-5020 Salzburg, Austria

${ }^{7}$ Environmental Geosphere Engineering Laboratory, Kyoto University, Katsura C1-2-215, Kyoto 615-8540, Japan

Corresponding author: Elco Luijendijk (elco.luijendijk@geo.uni-goettingen.de)

\section{Key Points:}

- Thermal springs in the Alps are exclusively fed by meteoric water which on average circulates to a depth of at least $2 \mathrm{~km}$

- On average the contributing area of springs in the Alps is $0.6 \mathrm{~km}^{2}$ and the thermal footprint is $6 \mathrm{~km}^{2}$

- Hydrothermal activity is highest in orogens with high relief and areas undergoing lithospheric extension 


\begin{abstract}
The extent of deep groundwater flow in mountain belts and its thermal effects are uncertain. Here, we use a new database of discharge, temperature and composition of thermal springs in the Alps to estimate the extent of deep groundwater flow and its contribution to the groundwater and heat budget. The results indicate that springs are fed exclusively by meteoric water and make up $0.1 \%$ of the total groundwater budget. Spring water circulates on average to a depth of at least 2 $\mathrm{km}$. The net heat extracted from the subsurface equals $1 \%$ of the background heat flow, which equals an average thermal footprint of $6 \mathrm{~km}^{2}$. Cooling by downward flow and heating by upward flow are three and two times higher than the net heat flow, respectively. Comparison with north American orogens show that hydrothermal activity is higher in areas with high relief or areas under extension.
\end{abstract}

\title{
Plain Language Summary
}

Groundwater that originates as rainfall may reach considerable depths in mountain belts. Groundwater can also transport heat and affect the heat budget of mountains. However, the amount of groundwater that circulates to deeper levels and the extent to which it affects subsurface temperatures is largely unknown. Here we analyze newly compiled data from hot springs in the Alps to quantify groundwater flow and its thermal effects. On average the groundwater discharging in springs reach a depth of at least $2 \mathrm{~km}$. The thermal spring water makes up a very small portion $(0.1 \%)$ of all the groundwater in the Alps, while almost all of the groundwater flows out into rivers and lakes or evaporates. However, the groundwater that feeds springs does affect temperatures of rocks considerably. During downward flow it cools the subsurface, and during upward flow it heats the subsurface.

\section{Introduction}

Deep groundwater flow in mountains belts affects fault strength (Hubbert \& Rubey, 1959; Wintsch et al., 1995), subsurface temperatures and heat flow (Bodri \& Rybach, 1998; Whipp \& Ehlers, 2007). Moreover, groundwater flow may connect the deep and shallow biospheres (Pedersen, 1993; Walvoord et al., 1999). Groundwater can penetrate large parts of the crust, as shown by stable isotopes of fault minerals (Person et al., 2007; Poulet et al., 2014) and elevated ${ }^{3} \mathrm{He} /{ }^{4} \mathrm{He}$ ratios in thermal springs (Hoke et al., 2000; Karlstrom et al., 2013; Umeda et al., 2007). However, in contrast to sedimentary basins, where borehole data has yielded information on the volume, composition and age of deep groundwater (Ferguson et al., 2018; Gleeson et al., 2016; Jasechko et al., 2017), the overall rate and extent of deep groundwater flow in orogens is largely unknown. Note that we define deep groundwater as groundwater at depths exceeding $200 \mathrm{~m}$, following the approximate lower boundary of the hydrologically active zone in orogens (Manning \& Caine, 2007).

Several studies have shown that groundwater flow can influence temperatures in orogens by tens of degrees (Bodri \& Rybach, 1998; Forster \& Smith, 1989; Maréchal et al., 1999). The extent of the thermal effects of groundwater flow has been a long-standing question, in particular in low-temperature thermochronology, where anomalous thermochronological ages are often 
caused by hydrothermal activity (Dempster \& Persano, 2006; Duddy et al., 1994; Louis et al., 2019). Models and data from thermal springs have suggested that in some regions in the Himalayas (Derry et al., 2009; Whipp \& Ehlers, 2007) or the Cascades (Ingebritsen et al., 1992) groundwater flow may be responsible for more than $50 \%$ of the heat transport. Yet, the overall contribution of groundwater flow to the heat budget of orogens has not been quantified systematically to our knowledge.

Thermal springs are the most visible surface expression of deep groundwater flow in orogens. Data on spring discharge and temperature offers opportunities to quantify deep groundwater flow and its thermal effects (Luijendijk, 2019; Manga, 2001). The only systematic compilation and analysis of thermal springs in orogens known to us covers North America (Ferguson \& Grasby, 2011). However, this study did not report the contribution of thermal springs to the groundwater and heat budget of orogens. Country-wide estimates of spring discharge and heat flow exist for Japan (Fukutomi, 1970; Sumi, 1980), but include a large number of pumping wells in addition to natural springs. Here, we report a new database of thermal springs in the Alps that includes temperature, discharge, hydrochemistry and isotope data. We use this database to quantify groundwater origin, circulation depth and the contribution of thermal springs to the groundwater and heat budget of the Alps. In addition, we compare the results to published data for orogens in North America and explore the relation between hydrothermal activity and relief, groundwater recharge and background heat flux.

\section{Methods}

Our database contains temperature, discharge, hydrochemistry $\left(\mathrm{pH}, \mathrm{TDS}\right.$, major ions, $\left.\mathrm{SiO}_{2}\right)$ and stable isotopes $\left({ }^{18} \mathrm{O},{ }^{2} \mathrm{H}\right)$ data for 394 thermal springs in the Alps, as described in more detail in supporting information S1 The dataset predominantly consists of natural springs, but also includes 32 springs that are tapped by wells that are less than $100 \mathrm{~m}$ deep. The dataset is available on Pangaea (Luijendijk et al., 2020).

The origin of spring water was assessed by comparing the $\delta^{18} \mathrm{O}$ and $\delta^{2} \mathrm{H}$ values in thermal springs to data of 25 precipitation stations in the Alps (IAEA \& WMO, 2019). In addition, the data were compared to typical values for water derived from magmatic devolatilization and metamorphic dehydration (Sheppard, 1986; Yardley, 2009). Groundwater circulation temperature was estimated using empirical $\mathrm{SiO}_{2}$ geothermometer equations (Verma et al., 2008) (Figure S1). The corresponding circulation depth was calculated by dividing the circulation temperature with the average geothermal gradient in the Alps, following the method of Grasby and Hutcheon (2001). Note that this calculation assumes that groundwater flow does not affect the geothermal gradient strongly, which may not be true in some cases. The calculated circulation temperatures and depths are minimum estimates, because empirical geothermometer equations may underestimate circulation temperatures and depth as they do not take into account mixing effects and precipitation of $\mathrm{SiO}_{2}$ during upward flow (Ferguson et al., 2009). Mixing between shallow and deep sources has been demonstrated for a number of springs in the Alps and may be relatively common (Buser et al., 2013; Sonney et al., 2012; Waber et al., 2017). Geochemical models indicate that the maximum circulation temperatures of the deep groundwater component may be double that of bulk samples (Diamond et al., 2018). 
The size of the contributing area for each spring was calculated by dividing spring discharge by recharge rate at the spring location (De Graaf et al., 2015).

Heat exchange between the subsurface and the groundwater that discharges in springs, as illustrated in Figure S2, is given by:

$$
\left.H=\rho_{f} c_{f}\left(T_{2}-T_{1}\right) Q-H_{v} \quad \text { (eq. } 1\right)
$$

where $\mathrm{H}$ is the heat gain or loss of water $(\mathrm{W}), \rho_{\mathrm{f}}$ is the water density $\left(\mathrm{kg} \mathrm{m}^{-3}\right), \mathrm{c}_{\mathrm{f}}$ is specific heat capacity of water $\left(\mathrm{J} \mathrm{kg}^{-1} \mathrm{~K}^{-1}\right), \mathrm{T}_{1}$ and $\mathrm{T}_{2}$ are groundwater temperature at the start and end of the flow path $(\mathrm{K})$ and $\mathrm{Q}$ is groundwater discharge $\left(\mathrm{m}^{3} \mathrm{~s}^{-1}\right)$. The term $\mathrm{H}_{\mathrm{v}}$ represents the heating of water caused by viscous dissipation, which is often small but can be important in relatively cold springs with a high relief in their contributing area (Manga \& Kirchner, 2004). Viscous dissipation is given by:

$$
\left.H_{v}=\rho_{f} g\left(h_{2}-h_{1}\right) Q \quad \text { (eq. } 2\right)
$$

where $h_{1}$ and $h_{2}$ are the hydraulic head at the start and the end of the flow path $(\mathrm{m})$. Note that for flow between the recharge point and the spring eq. 2 is equivalent to the equation for viscous dissipation by Manga and Kirchner (2004) that includes the elevation difference instead of the difference in hydraulic head $\left(\mathrm{h}_{2}-\mathrm{h}_{1}\right)$. However, for flow to and from circulation depth one needs to take into account the conversion of gravitational potential to and from elastic potential to account for the change in fluid pressure. We therefore use hydraulic head in eq. 2, which represents the potential energy of groundwater per unit weight (Hubbert, 1940).

The net heat exchange with the subsurface is calculated by substituting $\mathrm{T}_{1}$ by the average recharge temperature $T_{\mathrm{r}}(K)$ and by substituting $T_{2}$ by the spring temperature $T_{\mathrm{s}}(K)$ in eq. 1 . For the viscous dissipation term, $\mathrm{h}_{1}$ is substituted by the average elevation of the recharge area $\mathrm{Z}_{\mathrm{r}}(\mathrm{m})$ and $h_{2}$ is substituted by the elevation of the spring, $z_{s}(m)$. For heat exchange during downward flow we use the average recharge temperature $T_{r}(K)$ as a value for $T_{1}$ and the circulation temperature $T_{m}(K)$ as the value for $T_{2}$ in eq. 1. For the heat exchanged during upward flow $T_{m}$ is used for $T_{1}$ and the spring temperature $T_{s}$ is used for $T_{2}$. For the calculation of the viscous dissipation using eq. 2 , $\mathrm{h}_{1}$ is substituted by $\mathrm{z}_{\mathrm{r}}$ and $\mathrm{h}_{2}$ is substituted by $\mathrm{h}_{\mathrm{m}}$, the hydraulic head at the circulation depth. For the calculation of viscous dissipation during upward flow $\mathrm{h}_{1}$ is substituted by $h_{m}$ and $h_{2}$ by $z_{s}$.

The values of average recharge elevation $\left(\mathrm{z}_{\mathrm{r}}\right)$ and temperature $\left(\mathrm{T}_{\mathrm{r}}\right)$ are unknown. However, the bounds of these parameters can be estimated. The maximum elevation was calculated using from the highest elevation in the watershed that the spring was located in, using the Hydrobasin database (Lehner \& Grill, 2013) and elevation data (Danielson \& Gesch, 2011). The minimum estimate for recharge elevation was equal to the elevation of the spring. Similarly, the minimum and maximum bounds of the recharge temperature were calculated as the recharge temperature at the spring location and the recharge temperature at the highest elevation in the watershed. Recharge temperature was assumed to follow the average annual air temperature (Fick \& Hijmans, 2017). Circulation temperature was estimated using published $\mathrm{SiO}_{2}$ geothermometer equations (Verma et al., 2008). The hydraulic head at the circulation depth $\left(\mathrm{h}_{\mathrm{m}}\right)$ is unknown and was chosen as the mean of the spring elevation and the maximum recharge elevation. Note that the uncertainty in $h_{m}$ only affects viscous dissipation, which is a very small term for most springs. 
We compared the heat flux of thermal springs with published background conductive heat flow data in the Alps (International Heat Flow Commission, 2020), which yielded a mean background heat flow density of $76 \mathrm{~mW} \mathrm{~m}$, and a mean geothermal gradient of $26{ }^{\circ} \mathrm{C} \mathrm{km}^{-1}$ (see Text S2 and Figure S3 for more details). These values agree with a recently published thermal model of the lithosphere in the Alps (Spooner et al., 2020). Note that given the low amount of data and the low variation of heat flow (Spooner et al., 2020) we use a single value for heat flow and geothermal gradient. The thermal footprint of springs was calculated by dividing the net heat flux of each spring by the mean background heat flow density.

The net heat flux of springs in the Alps was compared with several mountain belts in North America using a published database of spring heat flow (Ferguson \& Grasby, 2011). Note that these values did not take into account viscous dissipation and heat flow may therefore have been slightly overestimated. In addition, we compared the spring discharge and heat flux for the Alps and North American orogens with average groundwater recharge (De Graaf et al., 2015), relief and the background heat flow of each orogen. We used the standard deviation of elevation (Danielson \& Gesch, 2011) as an indicator for relief. The background heat flow for North America was obtained using natural neighbor interpolation (Sibson, 1981) of heat flow data (Blackwell et al., 2011; Blackwell \& Richards, 2004) (see Figure S4).

\section{Results and discussion}

The thermal springs are relatively evenly distributed over the Alps, with an aerial density of one spring per $512 \mathrm{~km}^{2}$ and an average distance between springs of $13 \mathrm{~km}$. The mean temperature of the springs is $22{ }^{\circ} \mathrm{C}$. The warmest springs are located in northern Italy (Figure 1a), where the La Bollente spring (Bortolami et al., 1983) and Fonte Boiola (Waring \& Blankenship, 1965) measured $71{ }^{\circ} \mathrm{C}$ and $70{ }^{\circ} \mathrm{C}$, respectively. The highest rates of water discharge were observed in the eastern Alps (Figure 1c), where the Fontanon spring in Italy (Cantonati \& Spitale, 2009) and the Kroparica spring in Slovenia (Philipp, 2015) discharge $0.22 \mathrm{~m}^{3} \mathrm{~s}^{-1}$ and $0.31 \mathrm{~m}^{3} \mathrm{~s}^{-1}$, respectively. The locations, temperatures, and discharge magnitudes of thermal springs in the Alps are shown in Figure 1.

The mean discharge rate of 241 thermal springs is $1.2 \times 10^{-3} \mathrm{~m}^{3} \mathrm{~s}^{-1}$, and total discharge is $2.7 \mathrm{~m}^{3} \mathrm{~s}^{-1}$, which equals to an annual rate of $0.4 \mathrm{~mm} \mathrm{a}^{-1}$ when spread out evenly over the Alps. This total spring flow is only $0.08 \%$ of the average recharge rate in the Alps of $500 \mathrm{~mm} \mathrm{a}^{-1}$ (De Graaf et al., 2015). This means that a large majority of groundwater in the Alps follows shallow flow paths and discharges in rivers or lakes instead of in springs.

All the spring water plots within $1 \% \delta^{18} \mathrm{O}$ value of the global meteoric water line and local precipitation values, which indicates a meteoric origin of spring waters (Figure $2 \mathrm{a}$ ). The compiled $\mathrm{SiO}_{2}$ concentrations and the calculated values of circulation temperature and depth for 139 of the springs are shown in Figure $2 \mathrm{~b}, 2 \mathrm{c}$ and $2 \mathrm{~d}$. The circulation temperatures range up to $130{ }^{\circ} \mathrm{C}$, which corresponds a depth of $4700 \mathrm{~m}$ below the surface based on average conductive geothermal gradients in the Alps (see Text S2, Figure S3). The mean circulation temperature is $64{ }^{\circ} \mathrm{C}$, which is equal to a depth of $2100 \mathrm{~m}$ below the surface. Note that these depths are minimum estimates due to the limitations of the $\mathrm{SiO}_{2}$ geothermometer discussed in the Methods.

The calculated net heat flux of these mapped thermal springs in the Alps is shown in Figure 3 . The average net heat flux for thermal springs equals 0.4 to $0.7 \mathrm{MW}$. The reported range 
of heat flux and thermal footprint represent end-member (minimum and maximum) uncertainty estimates. Note that the net heat flux as defined here is equal to heat extracted from the subsurface and does not include viscous dissipation, which is discussed more detail below. The two springs with the highest net heat flux are the Urquelle in Villach, Austria, with a net heat flux of 7.0 to $11 \mathrm{MW}$ and Lavey-les-Bains in Switzerland with a net heat flux of 5.3 to $7.5 \mathrm{MW}$. The calculated net heat flux for 226 springs for which the average temperature and discharge rate are known equals 84 to $151 \mathrm{MW}$. The net heat flux for the entire Alps equals a spatially averaged heat flow density of 0.42 to $0.75 \mathrm{~mW} \mathrm{~m}^{-2}$. Comparison with the background heat flow density shows that the heat flux by thermal springs is equal to $0.5 \%$ to $1.0 \%$ of the regional background heat flux. The thermal footprint of the springs is on average 4.9 to $8.8 \mathrm{~km}^{2}$ (Figure $3 \mathrm{~d}$ ). This is much larger than the contributing area for each spring, which is on average $0.6 \mathrm{~km}^{2}$ (Figure $3 \mathrm{~b}$ ).

Viscous dissipation contributes 0 to $32 \%$ of the total heat output of thermal springs in the Alps. The high uncertainty of the contribution of viscous dissipation is due to the unknown elevation and hydraulic head in the contributing area of springs as discussed in the Methods. Viscous dissipation is the highest in low-temperature springs and is likely the dominant heating process for most springs with temperature lower than $15^{\circ} \mathrm{C}$ (Figure S5).

The net heat flux of the springs is a combination of the cooling of the subsurface by downward groundwater flow, and heating by upward groundwater flow (Figure S2). Cooling by downward groundwater flow for 64 springs with data on circulation temperature is equal to 55 to $97 \mathrm{MW}$ and heating by upward flow for these springs is calculated as 35 to $65 \mathrm{MW}$. In comparison, for these springs the net heat flux (difference between the heat flux by downward and upward flow) is estimated as 20 to $32 \mathrm{MW}$, which shows that the magnitudes of cooling and heating by groundwater flow are much higher than the net heat flux. This implies that the effects of deep groundwater flow on subsurface temperatures may be substantially higher than implied by the relatively modest net heat flux of thermal springs.

Comparison of the discharge and the net hydrothermal heat flux for orogens in North America (Fig. 4) shows that the thermal spring discharge and the heat flux of the Alps are relatively high. Note that in contrast to the Alps, the heat flux of other orogens may be overestimated because viscous dissipation was not taken into account. However, the differences in hydrothermal heat flux between the Alps and other orogens are higher than the relatively small contribution of viscous dissipation. We hypothesize that the differences in hydrothermal activity between the orogens can be explained by several factors. First, the Alps have a relatively high spring density (Figure 4c). Due to a lack of systematic exploration and mapping of springs it is unknown if this represents a real difference in hydrothermal activity or whether this simply represents a more complete database for the Alps. Second, the hydrothermal activity appears to be associated with topographic relief (Figure 4d). It is well known that relief controls the maximum hydraulic gradient and is a measure of the driving force available for deep groundwater flow (Forster \& Smith, 1988). Third, in orogens cut by fault systems presently in transtension and extension, fault permeability tends to promote deep groundwater circulation (De Paola et al., 2007; Grasby \& Hutcheon, 2001; Hartman et al., 2018; von Hagke et al., 2019). The Sierra Nevada orogen shows the highest hydrothermal activity (Figure 4d-f). Apart from the relatively high relief, this is likely caused by fault systems in the Sierra Nevada being dominated by active transtension (Bennett, 2011). The comparison between background heat flow and hydrothermal activity (Figure 4f) confirms earlier work that showed that background heat flow does not control spring heat flux (Ferguson \& Grasby, 2011). Instead, the hydrothermal activity 
in the western USA (Figure 4a) is most likely promoted by extensional tectonics and high strain rates that provide deep permeable flow paths along fault zones (Faulds et al., 2012). Note that in addition to the factors explored here, we anticipate that other factors such as lithology, deformation history, fault density and structural style may play a role in explaining thermal spring activity in orogens.

The contribution of thermal springs reported here is a minimum estimate for deep groundwater flow and its thermal effects. The net heat flux by thermal springs is probably higher because $43 \%$ of the thermal springs in the database had no temperature and discharge data. If one assumes that the distribution of temperature and discharge in the remaining springs would be the same as for the springs with data, then the net heat flux would be much higher and equal approximately $1 \%$ to $2 \%$ of the background heat flow. In addition, water discharging in thermal springs is likely to be only a part of the total amount of deep groundwater flow, because a large part of deep groundwater flow may form blind hydrothermal systems without associated thermal springs at the land surface. Large quantities of groundwater usually discharge diffusely into rivers or lakes, and may contain waters of hydrothermal origin, but relatively few estimates for the rate of spring versus diffuse discharge have been published. Analysis of $\mathrm{Ge} / \mathrm{Si}$ ratios in springs and rivers in a basin in the Himalayas showed that diffuse discharge equals $2 / 3$ and spring discharge equals $1 / 3$ of the total hydrothermal discharge (Derry et al., 2009). Similarly, in the Beowawe system in the Basin and Range Province, $2 / 3$ of the total hydrothermal discharge is diffuse discharge (Olmsted \& Rush, 1987). In the Alps, there is subsurface in-situ evidence for diffuse thermal water discharge in tunnels and boreholes. For example, the construction of a 75 $\mathrm{m}$ long tunnel in Font Salée in the French Alps resulted in discharge with an estimated heat output of 69 MW (Silvestre, 1991) that exceeds any of the natural springs in the Alps. Similarly, in Brigerbad, Switzerland (Buser et al., 2013), and La Léchère, French Alps (Thiébaud et al., 2010), shallow ( $<100 \mathrm{~m}$ ) boreholes have tapped artesian groundwater with a higher heat output than existing natural springs in the same locations.

\section{Summary and conclusions}

We present and analyze a new database of thermal springs in the Alps. Our analyses suggest that thermal springs are fed by meteoric water and the discharge of the springs comprises $0.1 \%$ of the total meteoric groundwater budget of the Alps. The circulation depth of the water that discharges in the springs ranges up to $4700 \mathrm{~m}$ and has a mean value of $2100 \mathrm{~m}$. This is an underestimate due to the limitations of the $\mathrm{SiO}_{2}$ geothermometer on which these numbers are based (Ferguson et al., 2009), which means that meteoric groundwater circulates in a substantial part of the upper crust.

The net heat flux by thermal springs is approximately 0.5 to $1.0 \%$ of the background heat flow of the Alps. The net heat flux is a combination of two larger terms: cooling by downward groundwater flow, and heating by upward groundwater flow, for which the magnitude is approximately three and two times the net heat flux, respectively. These terms are probably underestimated due to the underestimation of circulation temperatures. Spring heat flux is also underestimated because no temperature or discharge data were available for $43 \%$ of the springs in the Alps. In addition, given that not all deep groundwater flow discharges in thermal springs, the estimates reported here are a minimum estimate for total amount of deep groundwater flow and its contribution to the heat budget. Although the contribution to the total heat budget is small, hydrothermal activity can locally be important for subsurface temperatures and heat flow. 
The average thermal footprint of springs is $6 \mathrm{~km}^{2}$, which means that on average heat flow and temperatures are affected in an area with a radius of $900 \mathrm{~m}$ around active springs, and larger if one assumes that springs do not harvest all the background heat flow over a particular area but harvest a part of the background heat flow over a larger area. Comparison with orogens in North America shows that hydrothermal activity is highest in orogens with relatively high relief and areas undergoing extension or transtension.

\section{Acknowledgments, Samples, and Data}

EL and $\mathrm{CvH}$ acknowledge funding by the German Research Foundation (DFG) project 365246344, which is part of the special priority program Mountain Building Process in Four Dimensions. The thermal spring database has been published at Pangaea (Luijendijk et al., 2020). The notebooks used for data analysis have been published at Zenodo (Luijendijk, 2020) and are also available on GitHub (https://github.com/ElcoLuijendijk/thermal_springs_alps).

\section{References}

Bennett, S. (2011). Geothermal potential of transtensional plate boundaries. Transactions Geothermal Resources Council, 35 1(2004), 703-707.

Blackwell, D., \& Richards, M. C. (2004). The 2004 geothermal map of North America, explanation of resources and applications. Geothermal Resource Council Transactions, 28, 317-320.

Blackwell, D., Richards, M., Frone, Z., Batir, J., Ruzo, A., Dingwall, R., \& Williams, M. (2011). Temperature-at-depth maps for the conterminous U. S. and geothermal resource estimates. Transactions - Geothermal Resources Council, 35 2, 1545-1550.

Bodri, B., \& Rybach, L. (1998). Influence of topographically driven convection on heat flow in the Swiss Alps: a model study. Tectonophysics, 291(1-4), 19-27.

Bortolami, G. C., Cravero, M., Olivero, G. F., Ricci, B., \& Zuppi, G. M. (1983). Chemical and isotopic measurements of geothermal discharges in the Acqui terme district, Piedmont, Italy. Geothermics, 12(2-3), 185-197. https://doi.org/10.1016/0375-6505(83)90029-9

Buser, M., Eichenberger, U., Jacquod, J., Paris, U., \& Vuataz, F. (2013). Geothermie Brig-Glis, Geothermiebohrungen Brigerbad Phase 2: Schlussbericht Phase 2.

Cantonati, M., \& Spitale, D. (2009). The role of environmental variables in structuring epiphytic and epilithic diatom assemblages in springs and streams of the Dolomiti Bellunesi National Park (south-eastern Alps). Fundamental and Applied Limnology, 174(2), 117-133. https://doi.org/10.1127/1863-9135/2009/0174-0117

Craig, H. (1961). Isotopic variations in meteoric waters. Science, 133(3465), 1702-1703. https://doi.org/10.1126/science.133.3465.1702

Danielson, J. J., \& Gesch, D. B. (2011). Global multi-resolution terrain elevation data 2010 (GMTED2010). US Geol. Surv. Open File Rep, 1073, 25.

De Graaf, I. E. M., Sutanudjaja, E. H., Van Beek, L. P. H., \& Bierkens, M. F. P. (2015). A highresolution global-scale groundwater model. Hydrology and Earth System Sciences, 19(2), 
823-837. https://doi.org/10.5194/hess-19-823-2015

De Paola, N., Holdsworth, R. E., Collettini, C., McCaffrey, K. J. W., \& Barchi, M. R. (2007). The structural evolution of dilational stepovers in regional transtensional zones. Geological Society Special Publication, 290, 433-445. https://doi.org/10.1144/SP190.17

Dempster, T. J., \& Persano, C. (2006). Low-temperature thermochronology: Resolving geotherm shapes or denudation histories? Geology, 34(2), 73-76. https://doi.org/10.1130/G21980.1

Derry, L. A., Evans, M. J., Darling, R., \& France-Lanord, C. (2009). Hydrothermal heat flow near the Main Central thrust, central Nepal Himalaya. Earth and Planetary Science Letters, 286(1), 101-109.

Diamond, L. W., Wanner, C., \& Waber, H. N. (2018). Penetration depth of meteoric water in orogenic geothermal systems. Geology, 46(12), 1083-1066. https://doi.org/10.1130/G45394.1

Duddy, I. R., Green, P. F., Bray, R. J., \& Hegarty, K. A. (1994). Recognition of the thermal effects of fluid flow in sedimentary basins. Geological Society, London, Special Publications, 78(1), 325-345.

Faulds, J. E., Hinz, N., Kreemer, C., \& Coolbaugh, M. (2012). Regional patterns of geothermal activity in the Great Basin region, western USA: Correlation with strain rates. Transactions - Geothermal Resources Council, 36 2, 897-902.

Ferguson, G., \& Grasby, S. E. (2011). Thermal springs and heat flow in North America. Geofluids, 11(3), 294-301. https://doi.org/10.1111/j.1468-8123.2011.00339.x

Ferguson, G., Grasby, S. E., \& Hindle, S. R. (2009). What do aqueous geothermometers really tell us? Geofluids, 9(1), 39-48. https://doi.org/10.1111/j.1468-8123.2008.00237.x

Ferguson, G., Mcintosh, Jj. C., Grasby, S. E., Hendry, M. J., Lindsay, M. B. J., Jasechko, S., \& Luijendijk, E. (2018). The Persistence of Brines in Sedimentary Basins. Geophysical Research Letters, 45, 4851-4858. https://doi.org/10.1029/2018GL078409

Fick, S. E., \& Hijmans, R. J. (2017). WorldClim 2: new 1-km spatial resolution climate surfaces for global land areas. International Journal of Climatology, 37(12), 4302-4315.

Forster, C., \& Smith, L. (1988). Groundwater flow systems in mountainous terrain: 2. Controlling factors. Water Resources Research, 24(7), 1011-1023. https://doi.org/10.1029/WR024i007p01011

Forster, C., \& Smith, L. (1989). The Influence of Groundwater Flow on Thermal Regimes in Mountainous Terrain: A Model Study. Journal of Geophysical Research, 94(B7), 94399451. https://doi.org/10.1029/JB094iB07p09439

Fukutomi, T. (1970). Order of magnitude for total discharge-rate of heat energy from all of the hot spring localities in Japan. Geophysical Bulletin of the Hokkaido University, 23, 9-13. https://doi.org/10.14943/gbhu.23.9

Gleeson, T., Befus, K. M., Jasechko, S., Luijendijk, E., \& Cardenas, M. B. (2016). The global volume and distribution of modern groundwater. Nature Geoscience, 9(2), 161-167. https://doi.org/10.1038/ngeo2590

Grasby, S. E., \& Hutcheon, I. (2001). Controls on the distribution of thermal springs in the 
southern Canadian Cordillera. Canadian Journal of Earth Sciences, 38(3), 427-440. https://doi.org/10.1139/e00-091

Handy, M. R., M. Schmid, S., Bousquet, R., Kissling, E., \& Bernoulli, D. (2010). Reconciling plate-tectonic reconstructions of Alpine Tethys with the geological-geophysical record of spreading and subduction in the Alps. Earth-Science Reviews, 102(3-4), 121-158. https://doi.org/10.1016/j.earscirev.2010.06.002

Hartman, S. M., Paterson, S. R., Holk, G. J., \& Kirkpatrick, J. D. (2018). Structural and hydrothermal evolution of a strike-slip shear zone during a ductile-brittle transition, Sierra Nevada, CA. Journal of Structural Geology, 113, 134-154.

https://doi.org/https://doi.org/10.1016/j.jsg.2018.05.010

Hoke, L., Poreda, R., Reay, A., \& Weaver, S. D. (2000). The subcontinental mantle beneath southern New Zealand, characterised by helium isotopes in intraplate basalts and gas-rich springs. Geochimica et Cosmochimica Acta, 64(14), 2489-2507. https://doi.org/10.1016/S0016-7037(00)00346-X

Hubbert, M. K. (1940). The Theory of Ground-Water Motion. The Journal of Geology, 48(8), 785-944.

Hubbert, M. K., \& Rubey, W. W. (1959). Role of fluid pressure in mechanics of overthrust faulting: I. Mechanics of fluid-filled porous solids and its application to overthrust faulting. Bulletin of the Geological Society of America, 70(2), 115-166. https://doi.org/10.1130/0016-7606(1959)70[115:ROFPIM]2.0.CO;2

IAEA, \& WMO. (2019). Global Network of Isotopes in Precipitation: The GNIP Database.

Ingebritsen, S. E., Sherrod, D. R., \& Mariner, R. H. (1992). Rates and patterns of groundwater flow in the Cascade Range volcanic arc, and the effect on subsurface temperatures. Journal of Geophysical Research, 97(B4), 4-599.

International Heat Flow Commission. (2020). Global heat flow database.

Jasechko, S., Perrone, D., Befus, K. M., Bayani Cardenas, M., Ferguson, G., Gleeson, T., Luijendijk, E., McDonnell, J. J., Taylor, R. G., Wada, Y., \& Kirchner, J. W. (2017). Global aquifers dominated by fossil groundwaters but wells vulnerable to modern contamination. Nature Geoscience, 10(6), 425-429. https://doi.org/10.1038/ngeo2943

Karlstrom, K. E., Crossey, L. J., Hilton, D. R., \& Barry, P. H. (2013). Mantle 3He and CO2 degassing in carbonic and geothermal springs of Colorado and implications for neotectonics of the Rocky Mountains. Geology, 41(4), 495-498.

Lehner, B., \& Grill, G. (2013). Global river hydrography and network routing: baseline data and new approaches to study the world's large river systems. Hydrological Processes, 27(15), 2171-2186.

Louis, S., Luijendijk, E., Dunkl, I., \& Person, M. (2019). Episodic fluid flow in an active fault. Geology, 47(10), 938-942. https://doi.org/10.1130/G46254.1

Luijendijk, E. (2019). Beo v1.0: Numerical model of heat flow and low-temperature thermochronology in hydrothermal systems. Geoscientific Model Development, 12, 40614073. https://doi.org/10.5194/gmd-12-4061-2019 
Luijendijk, E. (2020). ElcoLuijendijk/thermal_springs_alps: Thermal springs Alps notebooks. Zenodo. https://doi.org/10.5281/zenodo.3780328

Luijendijk, E., Winter, T., Köhler, S., Ferguson, G., von Hagke, C., \& Scibek, J. (2020). Compilation of discharge, temperature, hydrochemistry and isotope data for thermal springs in the Alps. PANGAEA. https://doi.org/10.1594/PANGAEA.916089

Manga, M. (2001). Using springs to study groundwater flow and active geological processes. Annual Review of Earth and Planetary Sciences, 29, 201-228. https://doi.org/10.1016/S0950-1401(10)04008-5

Manga, M., \& Kirchner, J. W. (2004). Interpreting the temperature of water at cold springs and the importance of gravitational potential energy. Water Resources Research, 40(5), 1-8. https://doi.org/10.1029/2003WR002905

Manning, A. H., \& Caine, J. S. (2007). Groundwater noble gas, age, and temperature signatures in an Alpine watershed: Valuable tools in conceptual model development. Water Resources Research, 43(4). https://doi.org/10.1029/2006WR005349

Maréchal, J.-C., Perrochet, P., \& Tacher, L. (1999). Long-term simulations of thermal and hydraulic characteristics in a mountain massif: The Mont Blanc case study, French and Italian Alps. Hydrogeology Journal, 7(4), 341-354.

Olmsted, F. H., \& Rush, F. E. (1987). Hydrogeologic Reconnaissance of the Beowawe Geysers Geothermal Area, Nevada. Geothermics, 16(1), 27-46.

Pedersen, K. (1993). The deep subterranean biosphere. Earth Science Reviews, 34(4), 243-260. https://doi.org/10.1016/0012-8252(93)90058-F

Person, M., Mulch, A., Teyssier, C., \& Gao, Y. (2007). Isotope transport and exchange within metamorphic core complexes. American Journal of Science, 307(3), 555-589.

Philipp, S. (2015). Hydrochemistry and Isotopic Analysis of Deep (Partly Thermal) Wells and Springs in NW-Slovenia. Technische Universität.

Poulet, T., Veveakis, M., Herwegh, M., Buckingham, T., \& Regenauer-lieb, K. (2014). Modeling episodic fluid-release events in the ductile carbonates of the Glarus thrust. Geophys. Res. Lett, 7121-7128. https://doi.org/10.1002/2014GL061715.Received

Schmid, S. M., Fügenschuh, B., Kissling, E., \& Schuster, R. (2004). Tectonic map and overall architecture of the Alpine orogen. Eclogae Geologicae Helvetiae, 97(1), 93-117. https://doi.org/10.1007/s00015-004-1113-x

Sheppard, S. M. F. (1986). Characterization and isotopic variations in natural waters. Reviews in Mineralogy, 16, 165-184. https://doi.org/10.2138/rmg.1985.16.6

Sibson, R. (1981). A Brief Description of Natural Neighbor Interpolation. In V. Barnett (Ed.), Interpreting Multivariate Data (pp. 21-36). John Wiley \& Sons.

Silvestre, J. P. (1991). Thermalisme et minéralisme - Le thermalisme dans les Hautes Alpes Rapport fínal. In Rapport BRGM: Vol. R 33971 PA.

Sonney, R., Vuataz, F. D., \& Schill, E. (2012). Hydrothermal circulation systems of the Laveyles-Bains, Saint-Gervais-les-Bains and Val d'llliez areas associated with the Aiguilles Rouges Massif in Switzerland and France. In Bulletin fuer Angewandte Geologie (Vol. 17, 
Issue 1, pp. 29-47).

Spooner, C., Scheck-Wenderoth, M., Cacace, M., Götze, H.-J., \& Luijendijk, E. (2020). The 3D thermal field across the Alpine orogen and its forelands and the relation to seismicity. EarthArXiv. https://doi.org/10.31223/osf.io/9w4q3

Sumi, K. (1980). Relationship between the distributions of the Quatemary volcanoes and the rate of heat discharge by hot water in Japan. Bulletin of the Geological Survey of Japan, 31(6), 255-266.

Thiébaud, E., Dzikowski, M., Gasquet, D., \& Renac, C. (2010). Reconstruction of groundwater flows and chemical water evolution in an amagmatic hydrothermal system (La Léchère, French Alps). Journal of Hydrology, 381(3-4), 189-202. https://doi.org/10.1016/j.jhydrol.2009.11.041

Umeda, K., Sakagawa, Y., Ninomiya, A., \& Asamori, K. (2007). Relationship between helium isotopes and heat flux from hot springs in a non-volcanic region, Kii Peninsula, southwest Japan. Geophysical Research Letters, 34(5), 1-5. https://doi.org/10.1029/2006GL028975

Verma, S. P., Pandarinath, K., \& Santoyo, E. (2008). SolGeo: A new computer program for solute geothermometers and its application to Mexican geothermal fields. Geothermics, 37(6), 597-621. https://doi.org/10.1016/j.geothermics.2008.07.004

von Hagke, C., Kettermann, M., Bitsch, N., Bücken, D., Weismüller, C., \& Urai, J. L. (2019). The Effect of Obliquity of Slip in Normal Faults on Distribution of Open Fractures. Frontiers in Earth Science, 7, 18. https://doi.org/10.3389/feart.2019.00018

Waber, H. N., Schneeberger, R., Mäder, U. K., \& Wanner, C. (2017). Constraints on Evolution and Residence time of Geothermal Water in Granitic Rocks at Grimsel (Switzerland). Procedia Earth and Planetary Science, 17(February), 774-777. https://doi.org/10.1016/j.proeps.2017.01.026

Walvoord, M. A., Pegram, P., Phillips, F. M., Person, M., Kieft, T. L., Fredrickson, J. K., McKinley, J. P., \& Swenson, J. B. (1999). Groundwater flow and geochemistry in the Southeastern San Juan Basin: Implications for microbial transport and activity. Water Resour. Res., 35(5), 1409-1424. https://doi.org/10.1029/1999WR900017

Waring, G. A., \& Blankenship, R. R. (1965). Thermal Springs of the United States and Other Countries: A Summary (Vol. 492). US Government Printing Office.

Whipp, D. M., \& Ehlers, T. A. (2007). Influence of groundwater flow on thermochronometerderived exhumation rates in the central Nepalese Himalaya. Geology, 35(9), 851-854.

Wintsch, R. P., Christoffersen, R., \& Kronenberg, A. K. (1995). Fluid-rock reaction weakening of fault zones. J. Geophys. Res., 100(B7), 13021-13032. https://doi.org/10.1029/94JB02622

Yardley, B. W. D. (2009). The role of water in the evolution of the continental crust. Journal of the Geological Society, 166(4), 585-600. https://doi.org/10.1144/0016-76492008-101 


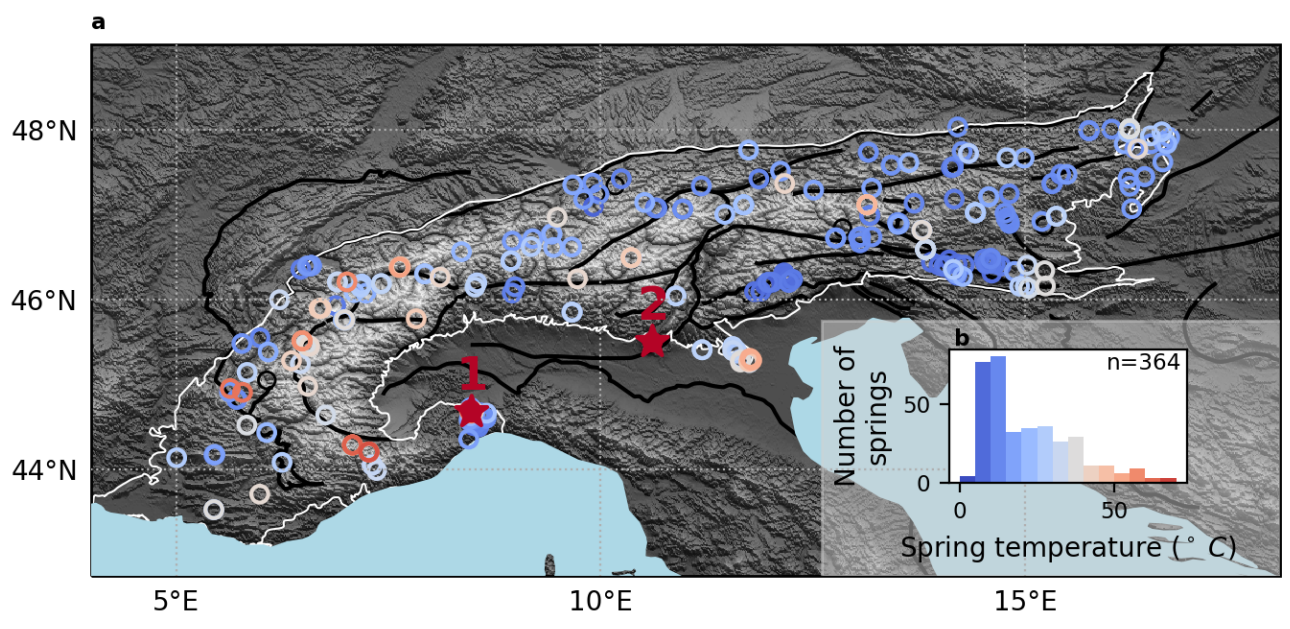

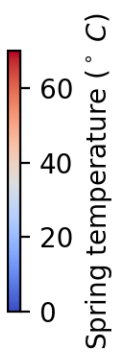

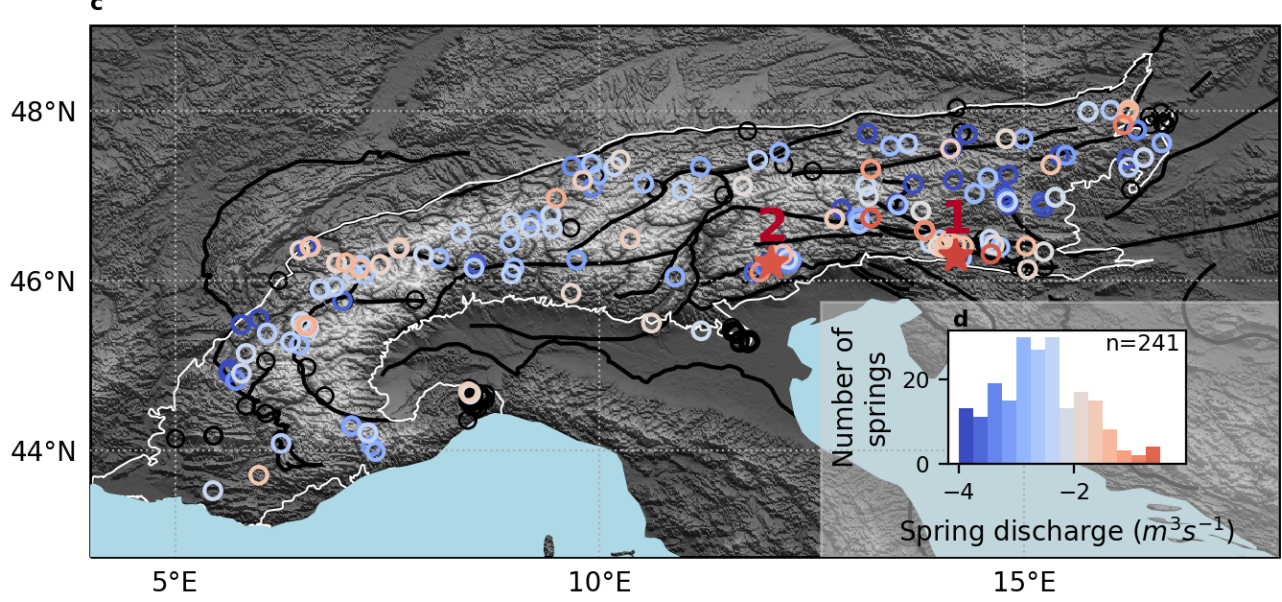

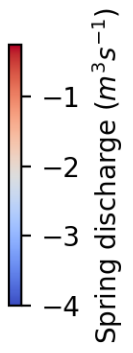

Figure 1. The location, temperature and discharge of thermal springs in the Alps. Panel a and c show maps of the temperature and discharge of thermal springs, respectively. Panel $b$ and $d$ show histograms of the temperature and discharge of thermal springs. The red numbers show the location of the two springs with the highest temperature (panel a) and discharge (panel c). Black circles denote springs without temperature or discharge data. The outline of the Alps is shown in white, and major fault zones are shown by black lines (Handy et al., 2010; Schmid et al., 2004). 

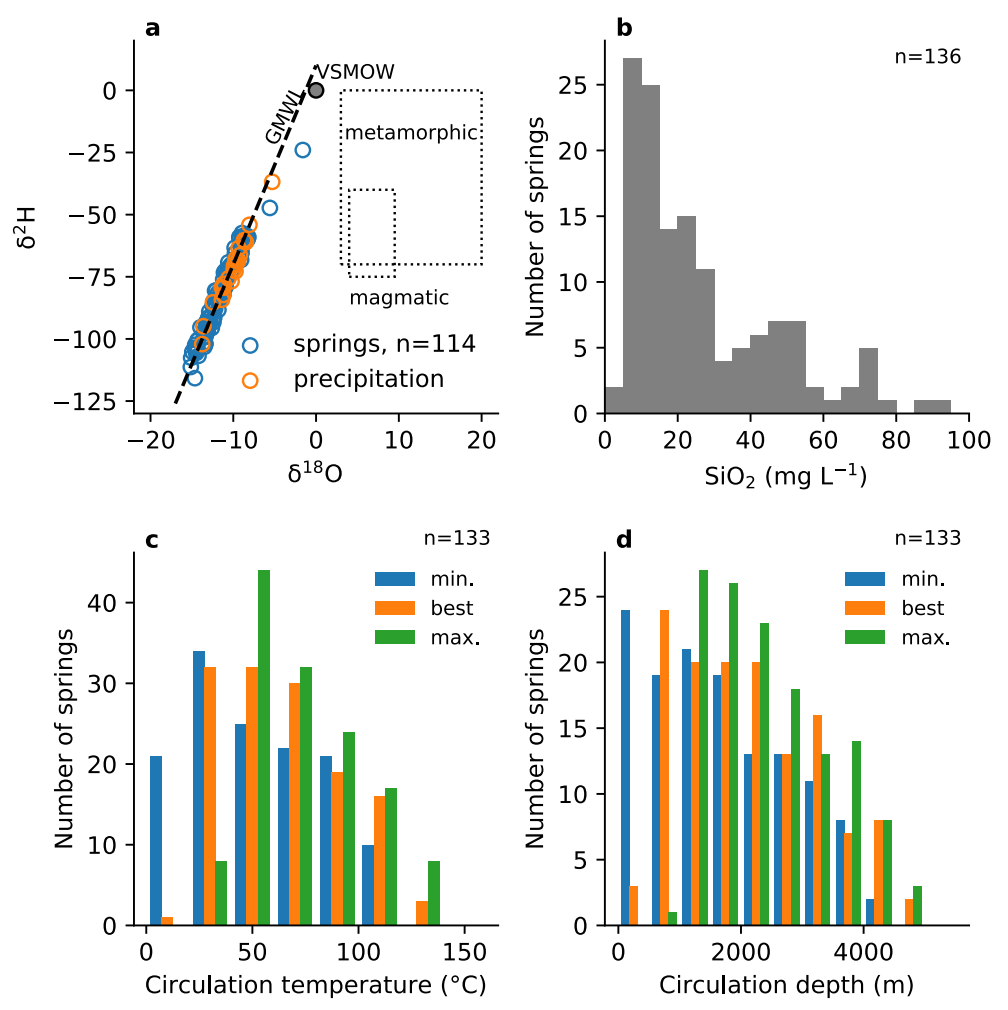

Figure 2. Source, circulation temperature and circulation depth of thermal spring water. (a) Comparison between $\delta^{2} \mathrm{H}$ and $\delta^{18} \mathrm{O}$ in spring water and in precipitation in the Alps and typical values for water derived from metamorphic and magmatic sources (Yardley, 2009). VSMOW denotes Vienna Standard Mean Ocean Water, GMWL denotes the global meteoric water line (Craig, 1961), (b) $\mathrm{SiO}_{2}$ concentration in thermal springs, (c) Calculated circulation temperature and (d) circulation depth. Circulation depth was calculated using the circulation temperature and an average geothermal gradient of $26^{\circ} \mathrm{C} \mathrm{km}^{-1}$. The min., max. and best values in panel $\mathrm{c}$ and $\mathrm{d}$ represent the circulation temperature and depth using the lowest, highest and mean value of the geothermometer equations, respectively. Note that for three springs the $\mathrm{SiO}_{2}$ value was lower than $5 \mathrm{mg} \mathrm{L-1}$, which is the lower limit for which the geothermometer equations are valid. 

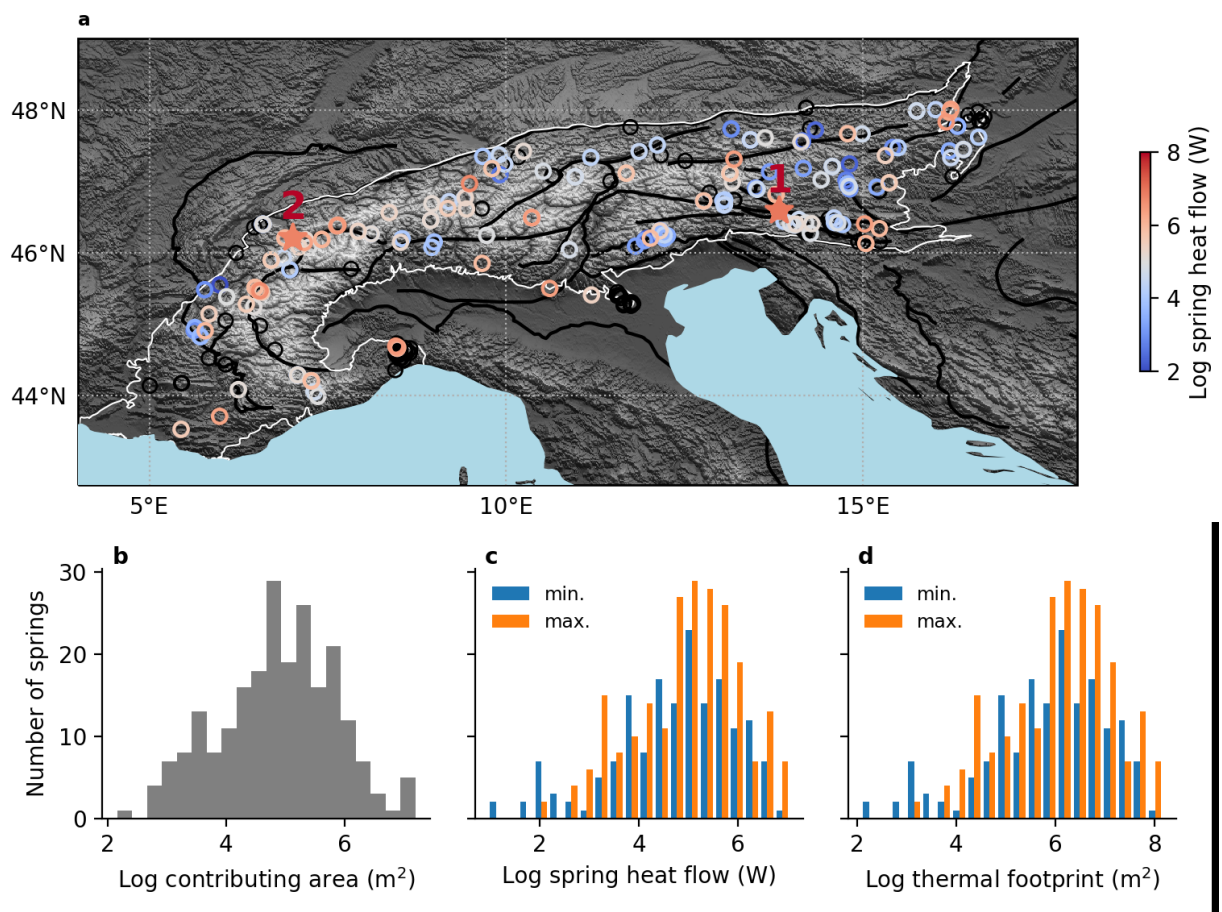

Figure 3. Calculated net heat flux, contributing area and thermal footprint for thermal springs in the Alps. Panel a shows a map of the best estimate spring heat flow, which is the mean of the minimum and maximum estimates discussed in the text. Black circles denote springs without temperature or discharge data. The outline of the Alps is shown in white, and major fault zones are shown by black lines (Handy et al., 2010; Schmid et al., 2004). Red numbers show the location of the two springs with the highest net heat flux. Panel b, $c$ and d show histograms of the calculated contributing area, net heat flow and thermal footprint of the springs, respectively. Panel $\mathrm{c}$ and $\mathrm{d}$ show min. and max. values that represent uncertainty ranges as discussed in the text. Note that we did not calculate an uncertainty range for contributing area. 

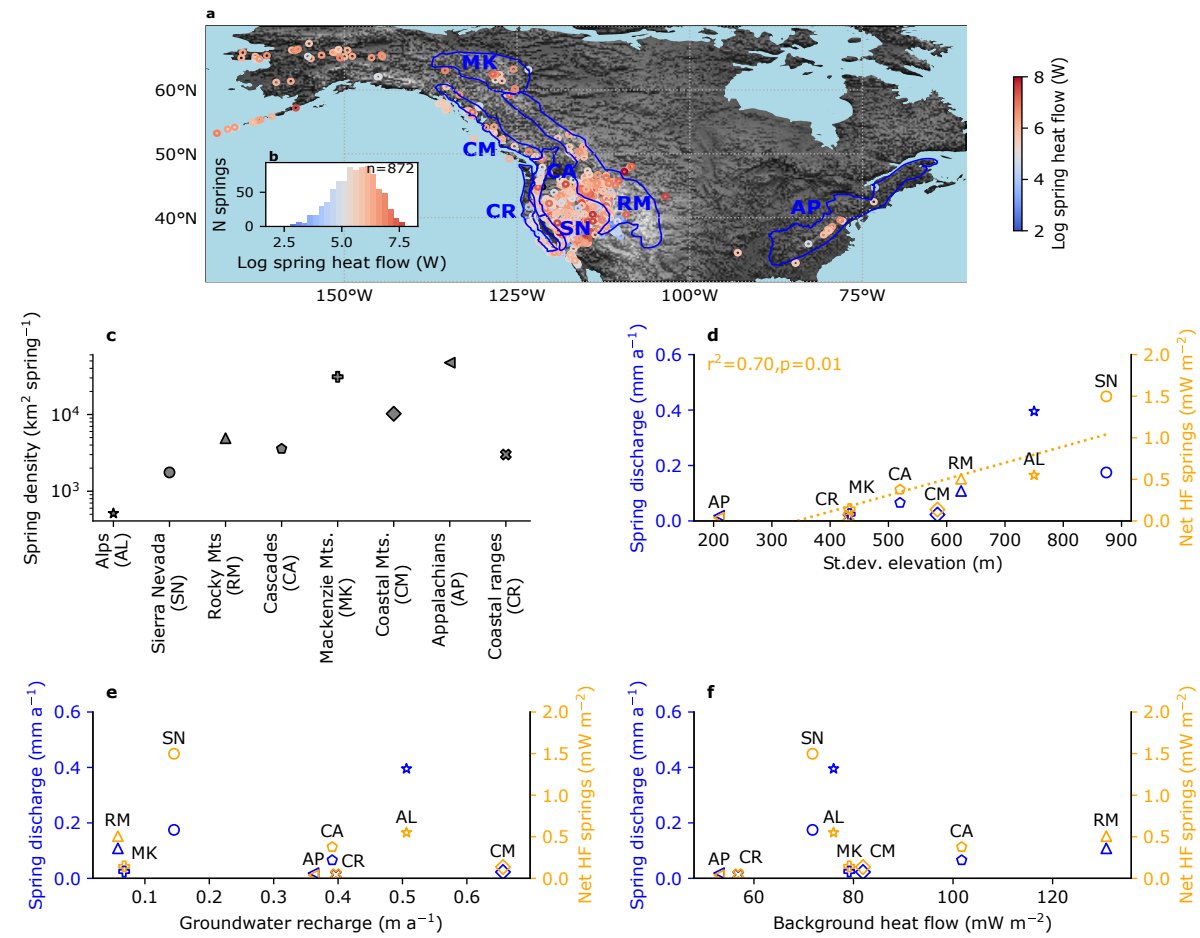

Figure 4. Comparison of thermal spring discharge and net heat flux by thermal springs in the Alps and number of orogens in North America with relief, groundwater recharge and background heat flow density. Panel a shows the net heat flux of thermal springs (Ferguson \& Grasby, 2011) and the locations of orogens in north America and inset panel $b$ shows the distribution of net heat flux. Panel c shows the spring density in the various orogens, and panels $\mathrm{d}$, e and $\mathrm{f}$ show the relation between thermal spring discharge and heat flux and relief, groundwater recharge and background heat flow, respectively. The only statistically significant correlation $(p<0.05)$ is the correlation between net heat flux and relief shown in panel $\mathrm{d}$. 


\title{
QAGUPUBLICATIONS
}

Geophysical Research Letters

Supporting Information for

\section{Using thermal springs to quantify deep groundwater flow and its thermal footprint in the Alps and North American orogens}

\author{
Elco Luijendijk ${ }^{1}$, Theis Winter ${ }^{1,2}$, Saskia Köhler ${ }^{1,3}$, Grant Ferguson ${ }^{4}$, Christoph von Hagke $^{5}$, Jacek Scibek \\ ${ }^{1}$ Department of structural geology \& geodynamics, University of Göttingen, Goldschmidtstrasse 3, 37077, Göttingen, Germany \\ ${ }^{2}$ Chair of Hydrogeology, Faculty of Civil, Geo and Environmental Engineering, Technical University of Munich, Arcisstr. 21,80333 \\ Munich, Germany \\ ${ }^{3}$ GeoZentrum Nordbayern, Universität Erlangen-Nürnberg, Schlossgarten 5, 91054 Erlangen, Germany \\ ${ }^{4}$ Department of Civil, Geological and Environmental Engineering, University of Saskatchewan, 57 Campus Drive, Saskatoon, \\ Canada
}

${ }^{5}$ Geological Institute of the RWTH Aachen University, Wüllnerstr. 2, 52056 Aachen, Germany.

${ }^{6}$ No fixed address at present (travelling through Japan)]

\section{Contents of this file}

Text S1 to S2

Figures $\mathrm{S} 1$ to $\mathrm{S} 8$

Table S1 


\section{Introduction}

The supporting information presented here provides more detail for the data compilation effort that led to the thermal spring database of the Alps (Text S1) and the calculation of the conductive background geothermal gradient and heat flow of the Alps (Text S2). In addition, the document includes six supporting figures that are cited in the main text and one supporting table that details the number and type of data included in the thermal spring database.

\section{Text S1: Thermal spring database.}

The thermal spring database is based on several existing databases, including a global database (Waring \& Blankenship, 1965) and a regional database for Switzerland (Sonney \& Vuataz, 2008). In addition, a large amount of data was obtained from published literature and technical reports. The database has been published at PANGAEA (Luijendijk et al., 2020) .More details on the data sources for each spring are included in the database.

The boundary of the Alps was based on published geological maps (Handy et al., 2010; Schmid et al., 2004). In addition to springs within the Alps, we included springs that were at a distance of up to 0.1 degree (approx. $10 \mathrm{~km}$ ) or less from the Alps, because these springs are likely to be driven by the high recharge and hydraulic gradients in the Alps.

Our objective was to only include natural springs. A number of natural springs have over time been tapped by shallow wells but are still referred to in the literature as springs. We included springs with shallow wells in the database and used a cutoff of $100 \mathrm{~m}$ to distinguish shallow and deep wells. The cutoff of $100 \mathrm{~m}$ was chosen such temperature of the water that discharges in these wells is not affected significantly by the increased background temperature at the depths at which these springs are tapped. Given the geothermal gradient is approximately 3 ${ }^{\circ} \mathrm{C}$ higher at a depth of $100 \mathrm{~m}$. Overall 32 of the 394 springs in the database consist of shallow wells, the remainder were natural springs. The distribution of the values of discharge and temperatures for these springs for discharge and temperature are similar to the distribution for the springs without wells (Figure S6). Therefore, including the springs tapped by shallow wells did not introduce a bias in our analysis.

\section{Text S2: Calculation of background geothermal gradients and heat flow.}

We compared the heat flux of thermal springs to the background conductive heat flow density in the Alps based on the global heat flow data database (International Heat Flow Commission, 2020) (Figure S3). The database consists of 181 datapoints with data on heat flow density and 19 points with data on geothermal gradients. With the area of the Alps of $202 \times 10^{3} \mathrm{~km}^{2}$ there is on average one heat flow datapoint per $1117 \mathrm{~km}^{2}$, and the average distance between datapoints is 19 $\mathrm{km}$. Note that for the calculation of the average geothermal gradient data from measurements in lake sediments were omitted, because these may not be representative of the deeper parts of the upper crust. The mean background heat flow is $76 \mathrm{~mW} \mathrm{~m}^{-2}$, and the mean geothermal gradient is $26{ }^{\circ} \mathrm{C} \mathrm{km}^{-1}$. Given the high variation in background heat flow at small spatial scales (Figure S3) no further attempt was made to interpolate heat flow density, and the mean heat flow density value was used for further analysis. The thermal footprint of springs was calculated by dividing the net heat flux of each spring by the mean background heat flow density in the Alps.

Background heat flow in North America (Figure S4) was based on detailed heat flow data that covers the USA (Blackwell et al., 2011; Blackwell \& Richards, 2004) and data from the 
global heat flow data database (International Heat Flow Commission, 2020). The data were interpolated on a 0.25 by 0.25 degree grid using natural neighbor interpolation (Sibson, 1981).

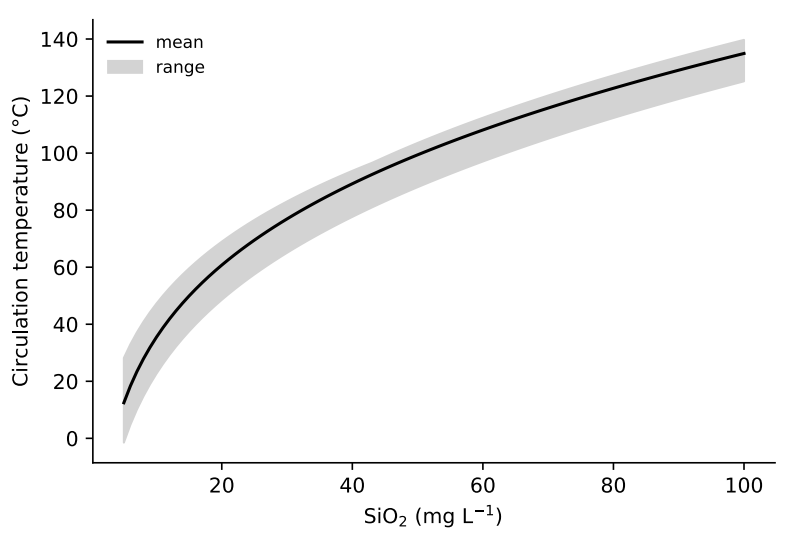

Figure S1 Theoretical relation between $\mathrm{SiO} 2$ concentration and minimum circulation temperature using a range of 9 geothermometer equations (Verma et al., 2008). The mean value represents the mean of the 9 different geothermometer equations

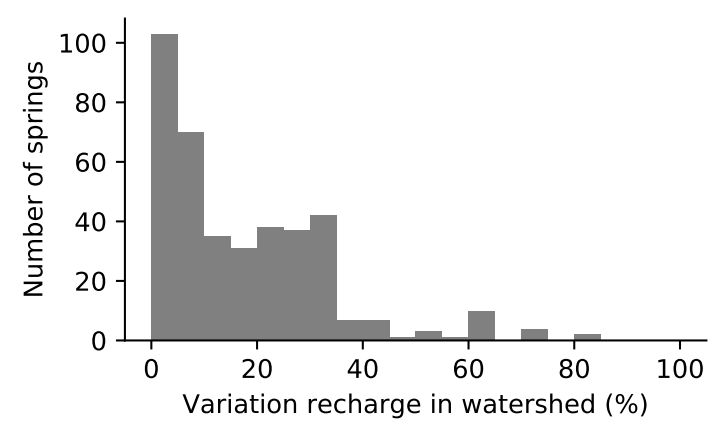

Figure S2. Variation of groundwater recharge in watersheds that host thermal springs. The variation was calculated as the difference between the minimum and maximum value divided by the maximum value. 


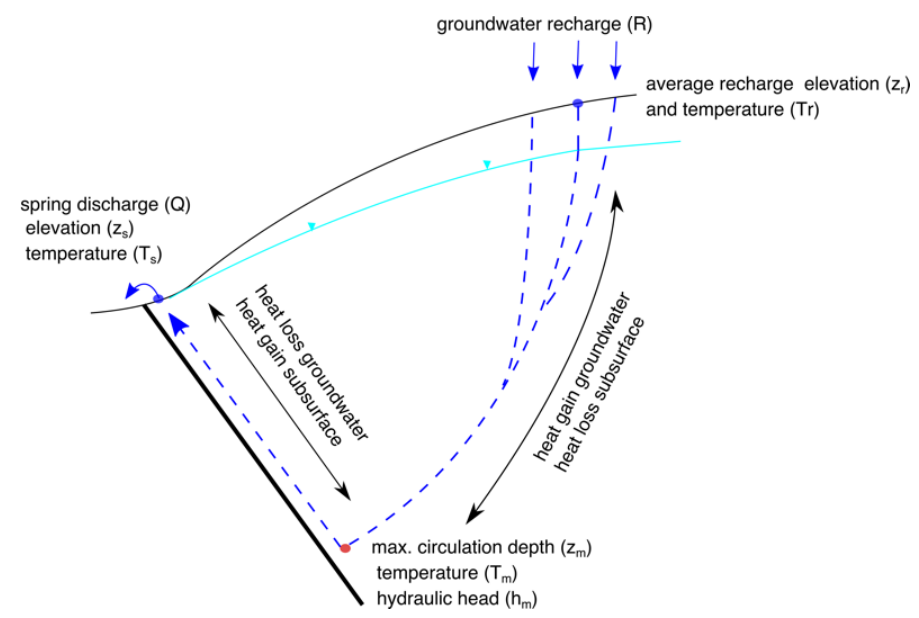

Figure S2. Conceptual model of the flow paths of groundwater that discharges in thermal springs and heat exchange between groundwater and the subsurface. 

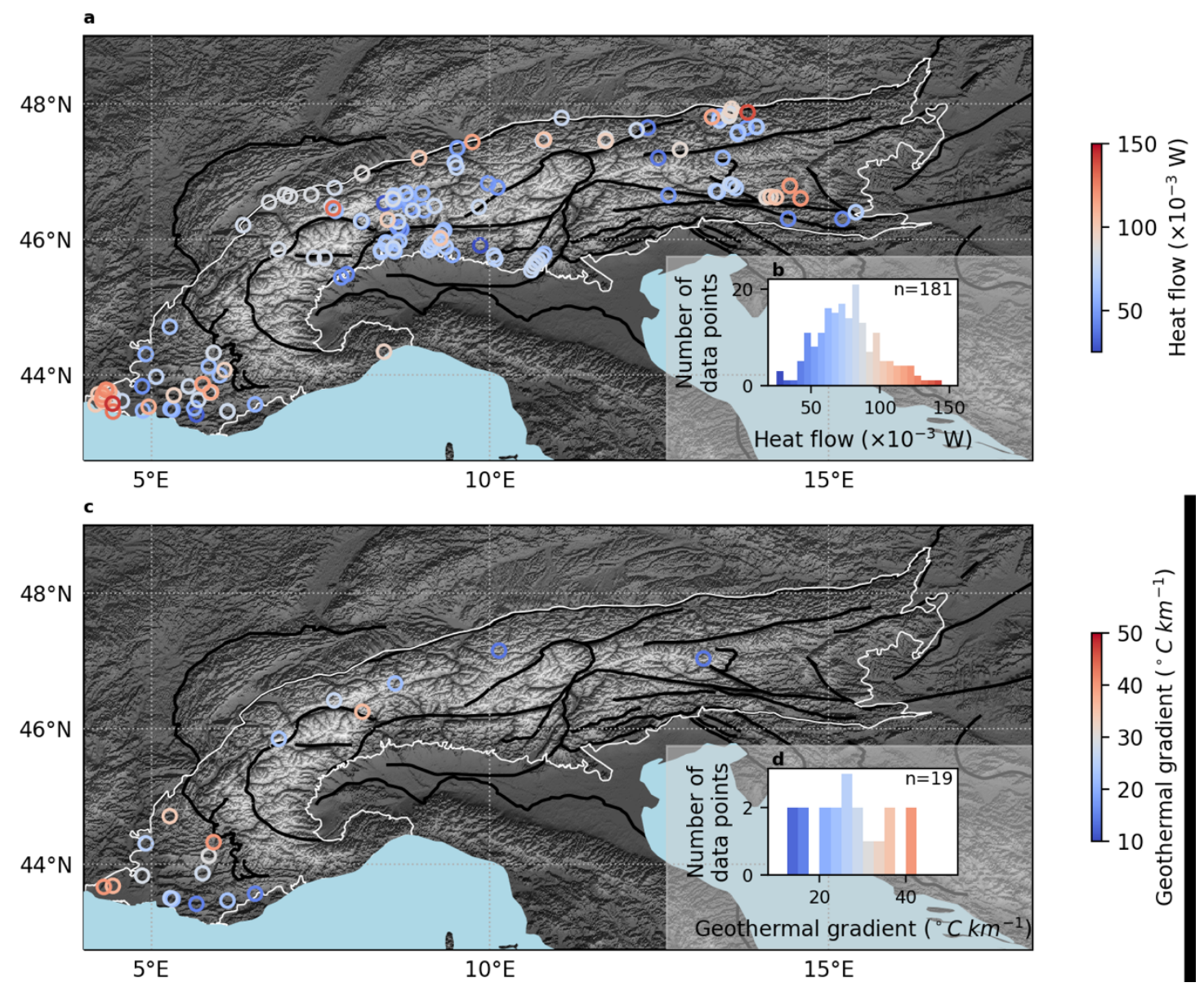

Figure S3. Map of the background heat flow density and geothermal gradient in the Alps. Panel $\mathrm{a}$ and $\mathrm{b}$ show heat flow and panel $\mathrm{c}$ and $\mathrm{d}$ show geothermal gradients. The data are based on the global heat flow database (International Heat Flow Commission, 2020). The outline of the Alps is shown in white, and major fault zones are shown by black lines (Handy et al., 2010; Schmid et al., 2004). Note that the map of geothermal gradient only contains data from boreholes, tunnels and mines. Data from measurements in lake bottom sediments were omitted. 

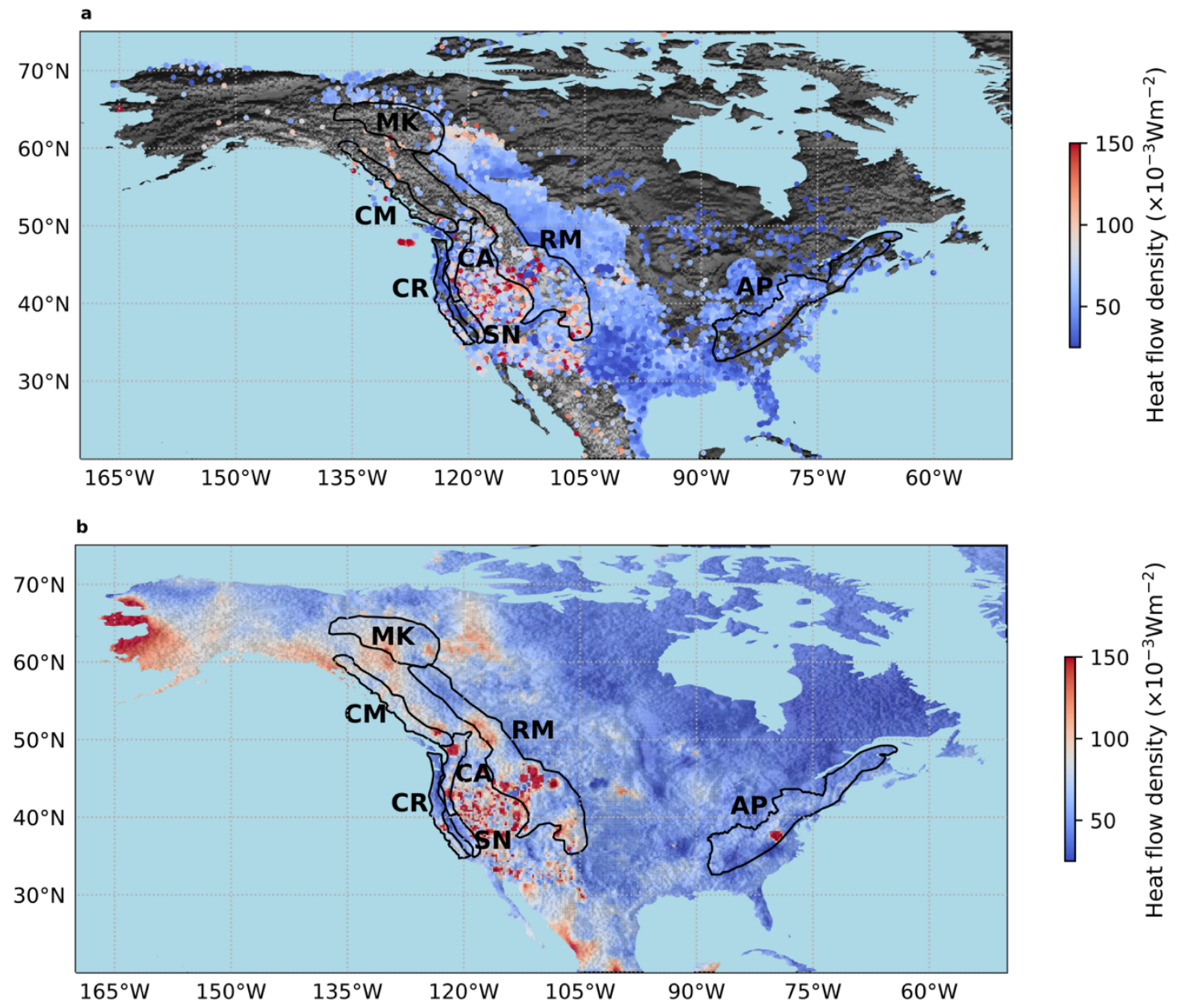

Figure S4. Map of the background heat flow density in North America. Panel a shows heat flow data (Blackwell et al., 2011; Blackwell \& Richards, 2004; International Heat Flow Commission, 2020) and panel b shows interpolated heat flow density. AP denotes the Appalachians, CA Cascades, CM coastal mountains, CR Coastal Ranges, MK McKenzie Mountains, RM Rocky Mountains, SN Sierra Nevada. 

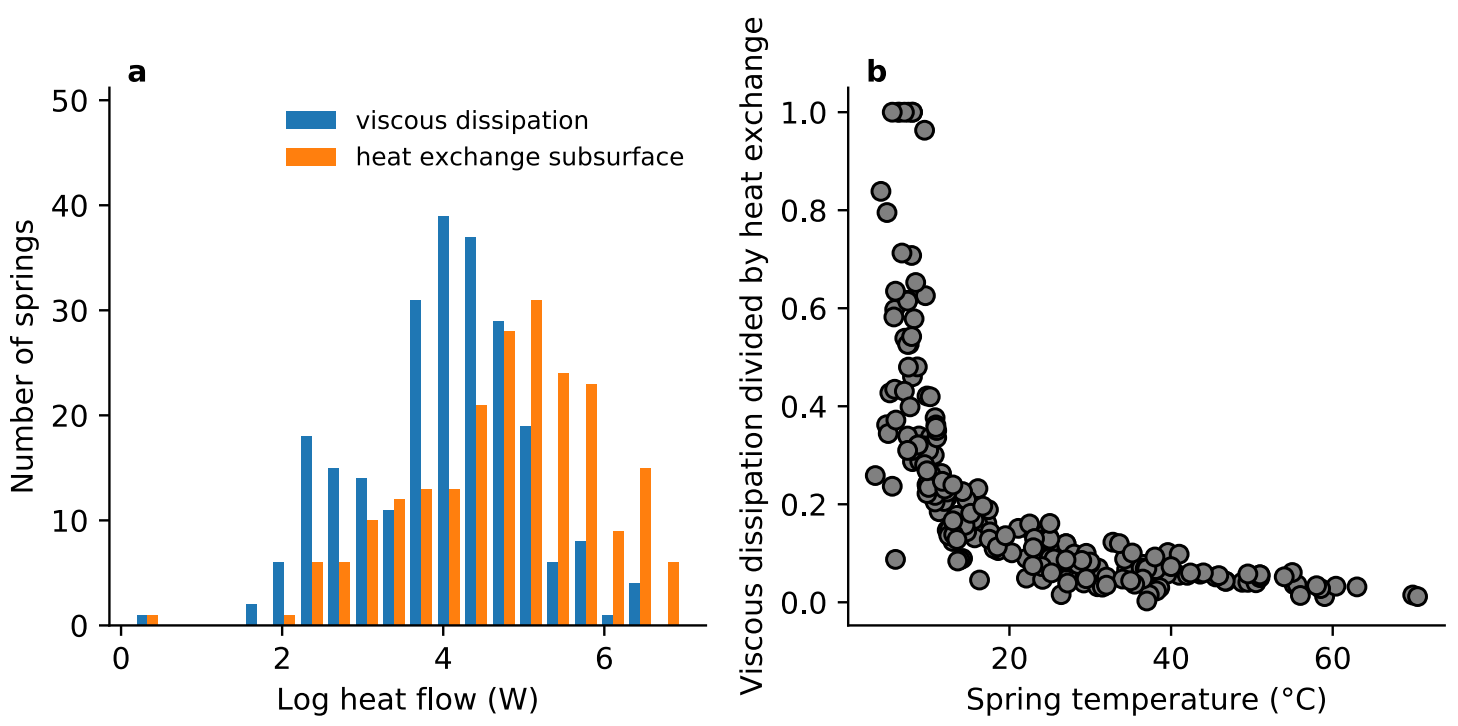

Figure

S5. Comparison of the contribution of viscous dissipation and heat exchange with the subsurface to the heat output of thermal springs in the Alps. Panel a shows the distribution of viscous dissipation and heat exchange for the springs. Panel $b$ shows the relation between spring temperature and the relative contribution of viscous dissipation, which demonstrates that viscous dissipation can be an important control on spring temperature for relatively cold springs. 

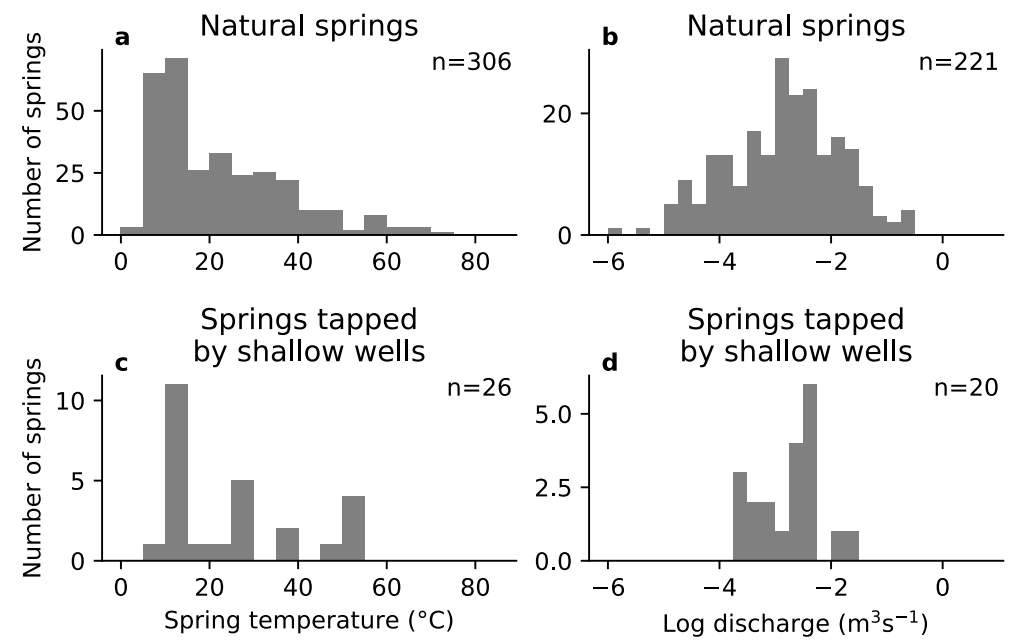

Figure S6. Comparison of temperature and discharge for natural springs and springs tapped by shallow $(<100 \mathrm{~m})$ wells. 
Table S1. Type of data available in the thermal spring database.

\begin{tabular}{|l|l|}
\hline Type of data & Number of springs \\
\hline Temperature & 364 \\
\hline Discharge & 241 \\
\hline Temperature and discharge & 226 \\
\hline Temperature or discharge & 379 \\
\hline${ }^{18} \mathrm{O}$ & 127 \\
\hline${ }^{2} \mathrm{H}$ & 115 \\
\hline $\mathrm{SiO}_{2}$ & 136 \\
\hline Total number of springs & $\mathbf{3 9 4}$ \\
\hline
\end{tabular}

